\title{
Integrasi Nilai Islam Multikultural dalam Pengembangan Perpustakaan Digital: Studi Kasus pada Perpustakaan Perguruan Tinggi Negeri di Malang Jawa Timur
}

\author{
Hartono \\ Perpustakaan Proklamator Bung Karno Blitar \\ email: hartono_hary@yahoo.co.id
}

\begin{abstract}
Abstrak
Penelitian ini menggunakan pendekatan deskriptif kualitatif dengan paradigma kajian pengembangan perpustakaan digital dalam membangun aksesibilitas informasi berbasis nilai Islam multikultural. Metode pengumpulan data dalam penelitian ini melalui wawancara, observasi dan dokumentasi. Teknik pengumpulan data melalui wawancara mendalam (dept interview) dan pemilihan objek dalam penelitian ini dengan teknik purposive sampling dengan 12 (duabelas) informan terdiri unsur kepala perpustakaan, kepala bidang, pengelola koleksi digital, pustakawan pengelola layanan digital dan mahasiswa. Metode analisis yang digunakan dalam penelitian ini mengacu pada proses analisis yang dikemukakan oleh Miles dan Huberman yang meliputi 3 (tiga) tahap, yaitu reduksi data, penyajian data, dan kesimpulan.

Hasil penelitian ini mengungkapkan bahwa strategi pemgembangan perpustakaan digital kedalam 3 (tiga) pola pendekatan antara lain pendekatan manajemen yang didasarkan pada perumusan konsep desain dan perancangan, pengembangan koleksi yang beragam, dan kebijakan / regulasi akses dan kedua, modernitas teknologi informasi, ketiga integrasi nilai multikultural melalui penguatan pada nilai demokrasi informasi melalui keterbukaan akses (open access), modernitas teknologi informasi berbasis humanisme, kesadaran hukum dan keadilan dalam legalitas informasi, kebersamaan resource sharring dan mengembangkan toleransi dalam membangun kesadaran yang saling menghargai dalam layanan perpustakaan digital. Integrasi nilai multikultural dalam erspektif teknis, manajemerial kepustakawanan, budaya sebagai pijakan yang mendasari dalam pengembangan perpustakaan di era digital
\end{abstract}

\author{
Kata Kunci: \\ Islam Perpustakaan Digital \\ Aksesibilitas Informasi \\ dan Multikultural
}

\section{A. PENDAHULUAN}

Dalam era informasi dewasa ini yang ditandai dengan perubahan perilaku masyarakat dalam mencari informasi. Dinamika perpustakaan juga terjadi perubahan sebagaimana pandangan dari Ranganathan bahwa perpustakaan merupakan organisasi yang tumbuh "growing organism". Transformasi Perpustakaan tersebut mampu beradaptasi sebagai lembaga demokratis yang membangun aksesibilitas informasi serta berupaya memenuhi tuntutan dan kebutuhan masyarakat dalam menjawab tantangan zaman (Zulaikha, 2010).

Modernitas lembaga perpustakaan perguruan tinggi yang demokratis mengharuskan layanan perpustakaan yang beragam dan bervariasi sehingga masyarakat dapat mencari informasi dengan cepat dan tepat. Perkembangan teknologi informasi yang sangat cepat tersebut telah merubah cara kerja dan sistem manajemen yang mampu mempercepat kinerja, kecepatan kinerja dan meningkatkan keuntungan dan omset yang masuk baik secara finansial maupun jaringan. Kemajuan teknologi dan informasi menuntut peran perpustakaan dalam menyediakan informasi, mengorganisasi, melestarikan, dan mendayagunakan serta mendesiminasikan informasi kepada masyarakat secara cepat, mudah, dan murah dengan memanfaatkan kemajuan teknologi informasi (Supriyanto \& Muhsin, 2008). 
Dinamika perpustakaan digital dari berbagai inovasinya telah merambah pada segala aspek kehidupan masyarakat, bukan saja untuk kebutuhan mencari informasi dilingkungan pendidikan tinggi saja namun sudah merambah kepada seluruh lapisan masyarakat. Modernisasi perpustakaan juga telah diadopsi dalam Undang-Undang Nomor 43 Tahun 2007, Bab V pasal 14 ayat 3 disebutkan bahwa setiap perpustakaan mengembangkan layanan perpustakaan sesuai dengan kemajuan tekonologi informasi dan komunikasi. Heterogenitas sumber informasi perpustakaan dari berbagai jenis karya tulis, karya cetak, karya rekam, dan karya digital mengharuskan layanan membutuhkan teknologi aksesibilitas informasi perpustakaan digital yang semakin canggih dan profesional. Kecanggihan aksesibilitas informasi merupakan faktorkunci dalam mencari sumber informasi yang memungkinkan koleksi dapat ditemukan dengan cepat, mudah, dan akurat. Bertolak dari pemikiran tersebut, masalah aksesibilitas informasi menjadi permasalahan dalam pengembangan perpustakaan digital.

Fenomena kepustakawanan tersebut telah menjadikan objek yang menarik untuk diteliti dalam dalam memahami perpustakaan digital dalam membangun aksesibilitas informasi. Kesenjangan informasi dan kemudahan akses (accessibility) menjadi faktor penting dalam pengembangan perpustakaan digital. Praktek dan interaksi sosial aksesibilitas informasi tersebut merupakan isu sentral dalam pengembangan perpustakaan digital pada Perpustakaan Perguruan Tinggi Negeri di Malang.

Bertolak dari pemikiran di atas dalam upaya mengembangkan perpustakaan digital terdapat akumulasi unsur antara lain aspek manajemen, teknologi dan nilai multikultural. Karena itu, untuk mengembangkan perpustakaan digital perlu membangun strategi implementasi manajemen, pengembangan teknologi dan pendekatan nilai keragaman budaya.

\section{B. KAJIAN TEORITIS \\ Islam, Nilai Multikultural dan Perpustakaan Digital}

Perpustakaan merupakan produk budaya sekaligus representasi dari berbagai budaya nusantara yang melakukan tugas dan perannya dalam menyediakan informasi, mengelola informasi, serta mendesiminasikan informasi kepada pemustaka yang beragam. Pengembangan koleksi dan informasi baik tercetak, tertulis, terekam dan digital maupun tulisan-tulisan pada dasarnya merupakan ekspresi kebudayaan. Pembangunan perpustakaan digital merupakan integrasi terhadap keragaman budaya baik dalam konteks koleksi yang dihimpun, diorganisasikan, serta keberagaman masyarakat.

Nilai-nilai multikultural tersebut sebagaimana disampaikan Wilson (Aly, 2011) menjelaskan bahwa nilai multikultural bersumber dari 3 (tiga) karakteristik adalah sebagai berikut: (1) nilai demokrasi yang berorientasi pada demokrasi, kesetaraan, dan keadilan: (2) nilai humanisme yang berorientasi pada kemanusiaan, kebersamaan, dan kedamaian; dan (3) nilai toleransi yang berorientasi pada pengembangan sikap mengakui, menerima, dan menghargai keragaman budaya (Baidhawy, 2005).

Kemudian untuk membahas tema ini juga mengadopsi teori menurut Gollnick dan Chinn menjelaskan bahwa nilai-nilai multikultural adalah pemahaman, pengakuan, dan penerapan tentang pentingnya nilai-nilai sebagai berikut: demokrasi, keadilan, humanisme, kebersamaan, dan toleransi. Nilai-nilai tersebut berhubungan dengan orang lain yang mempunyai latar belakang kultural berbeda seperti perbedaan agama, ras, etnis, bahasa, asal suku bangsa, gender, kemampuan /disabilitas, umur, kelas sosial, dan lain-lain (Gollnick \& Chin, 1998).

Dalam Kamus Besar Bahasa Indonesia $(\mathrm{KBBI})$, "multikulturalisme" mengandung 
pengertian keadaan dari sebuah masyarakat yang ditandai dengan menggunakan lebih dari satu kebiasaan. Keragaman budaya atau multikulturisme adalah sebuah ideologi dan sebuah alat untuk meningkatkan derajat manusia dan kemanusiaannya. "Multikulturalisme" pada dasarnya adalah pandangan dunia yang kemudian dapat diterjemahkan dalam berbagai kebijakan kebudayaan yang menekankan penerimaan terhadap realitas keagamaan, pluralitas, dan multikultural yang terdapat dalam kehidupan masyarakat. Multikulturalisme dapat juga dipahami sebagai pandangan dunia yang kemudian diwujudkan dalam kesadaran politik (Baidhawy, 2005).

Dalam perspektif Islam multikulturalisme dalam implementasinya dapat diuraikan bahwa perpustakaan sebagai sumber informasi, sarana pendidikan, transformasi nilai-nilai, agen perubahan bangsa. Maka, dalam konteks perpustakaan dan kepustakawanan pandangan Islam terhadap multikultural dapat dijelaskan sebagai berikut : (a) perpustakaan merupakan sumber informasi yang mampu mengembangkan nilai dan moral masyarakat untuk hidup rukun, (b) perpustakaan berperan dalam menjunjung tinggi sikap saling menghargai, (c) perpustakaan sebagai sarana mencerdaskan bangsa sekaligus mendukung kebebasan berpikir dan akses informasi, (d) perpustakaan perlu menunjukkan apresiasi dan interdependensi dengan menyediakan koleksi yang relevan. (e) perpustakaan juga lembaga publik mampu menanamkan nilai dan moral masyarakat untuk dapat mengembangkan toleransi dengan melakukan resolusi konflik dan kekerasan, (f) perpustakaan sebagai lembaga publik dituntut menyelenggarakan layanan perpustakaan secara demokratis dan menghargai perbedaan tanpa harus membedakan suku, ras, agama, dan golongan (Rifai, 2013).
Menurut Steenerova, dalam mengembangkan perpustakaan digital perlu dibangun pola pikir dengan pendekatan budaya dan bersifat holistik (Laksmi, 2006). Dengan kata lain bahwa pengembangan dan inovasi tidak hanya dilihat dari sudut rasionalitas, tetapi juga dari sudut manusia yang hidup dalam sistem budayanya, yang muncul dalam bentuk interaksi antara mereka dan interaksi antara mereka dengan lingkungan. +urut Wilson dan Kuhltau, proses pencarian informasi serta kompleksitas interaksi tersebut dapat dilakukan dari berbagai pendekatan, seperti fenomenologi dan hermeneutika dengan teknik interpretasi. Dengan mengetahui hal tersebut dapat menggambarkan kompleksitas manusia dalam lingkungan informasi. Berdasarkan asumsi di atas, permasalahan utama dalam implementasi perpustakaan terletak pada strategi pengembangan perpustakaan digital dalam membangun aksesibilitas informasi berbasis pada nilai keberagaman.

Dalam konteks manajemen, perpustakaan digital melaksanakan tugas dalam menghimpun, mengelola, melestarikan, dan melayankan koleksi kepada masyarakat dengan berbasis pada koleksi digital yang dapat diakses secara online melalui jaringan. Berkaitan dengan konsep perpustakaan digital tersebut, maka dapat dipahami perpustakaan digital berkaitan dengan bagaimana mendigitalisasikan obyek/bahan dan menyediakannya secara online, bagaimana memasukkan informasi baru yang belum memiliki bentuk penyajian secara nyata seperti layaknya koleksi perpustakaan, dan bagaimana menemukan bahan-bahan dalam perpustakaan digital.

Hubungan antara peran manajemen, teknologi, dan keragaman budaya dalam pengembangan perpustakaan digital sebagaimana disampaikan Ostrov (1998) tampak pada gambar berikut ini : 


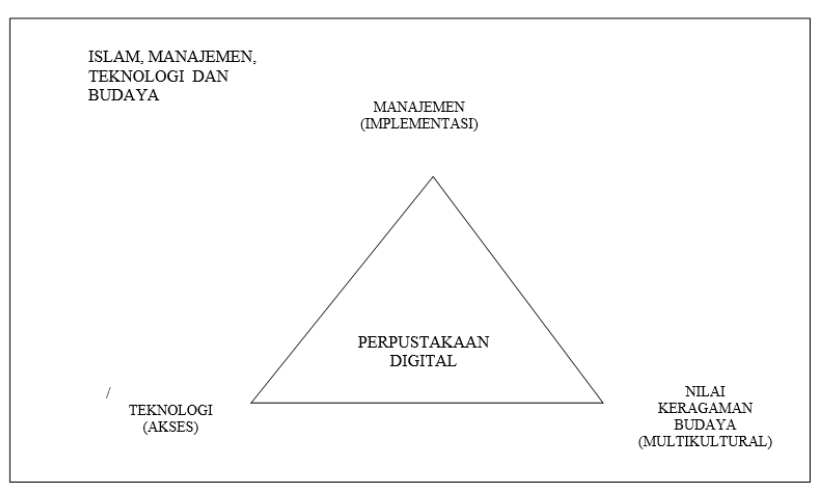

(Gambar 1 Korelasi Manajemen, Teknologi dan Budaya)

Berdasarkan Gambar diatas dapat dijelaskan bahwa dalam masyarakat yang beranekaragam budaya, tugasperpustakaanmenjadisangatstrategis dalam menghimpun, mengelola, mengolah, melestarikan koleksi, dan mendayagunakan koleksi perpustakaan, serta melayankan kepada pemustaka yang beraneka ragam budaya (multicultural). Modernitas perpustakaan pada era informasi bukan saja dihadapkan pada masalah teknologi dan akses, tetapi juga dihadapkan pada permasalahan sosial dan budaya (Ostrov, 1998). Perpustakaan perguruan tinggi negeri di Malang telah berupaya mengembangkan koleksi dalam upaya mendukung pengembangan perpustakaan digital. Perpustakaan Perguruan Tinggi di Malang juga telah mengorganisasikan koleksi digitalnya dengan mengembangkan format metadata serta membangun layanan perpustakaan digital dengan berbagai inovasinya. Di samping itu perpustakaan perguruan tinggi negeri di Malang telah mengimplementasikan sistem informasi perpustakaan digital dengan didukung teknologi informasi yang memadai.

\section{METODE PENELITIAN}

Penelitian ini merupakan jenis penelitian deskriptif dengan pendekatan kualitatif, dengan paradigma batasan penelitian kajian strategi pengembangan perpustakaan digital dalam membangun aksesibilitas informasi berbasis nilai Islam multikultural pada Perpustakaan Perguruan Tinggi negeri di Malang Jawa Timur. Pemilihan 3 (tiga) Universitas perguruan tinggi negeri di Malang didasarkan pertimbangan hasil observasi dalam penetapan lokasi penelitian.

Metode pengumpulan data menggunakan observasi, dokumentasi dan wawancara mendalam (in-depth interview). Pemilihan objek dalam penelitian ini dengan teknik purposive sampling. Informan ditetapkan berjumlah 12 (duabelas) informan terdiri unsur pimpinan mperpustakaan, pengelola koleksi digital, bagian pengelola layanan digital dan pemustaka.

Pengolahan data penelitian ini mengacu pada proses analisis yang dikemukakan oleh Miles dan Huberman yang meliputi 3 (tiga) tahap, yaitu reduksi data, penyajian data, dan kesimpulan. Keabsahan data dilakukan dengan menggunakan uji trianggulasi yaitu teknik pemeriksaan dan keabsaan data dengan mengecek baik derajat kepercayaan suatu informasi.

\section{HASIL DAN PEMBAHASAN}

Pada tahun 2004 Perpustakaan Perguruan Tinggi Negeri di Malang telah berhasil mengimplementasikan automasi perpustakaan berbasis web. Melalui berbagai program manajemen melakukan kerjasama dan pengembangan lainnya, perpustakaan Universitas Brawijaya (UB) memperoleh penghargaan sebagai perpustakaan yang mengembangkan dan menerapkan information technology (IT) dengan baik. Pada tahun yang sama Perpustakaan Pusat UM Malang menjadi perpustakaan unggulan perpustakaan Perguruan Tinggi di Jawa Timur yang berhasil mengembangkan perpustakaan digital.

Pada tahun 2010 perpustakaan UIN Malang menjadi pioneer di lingkungan perguruan tinggi negeri dan PTAIN ditanah air membangun instituational repository dan melayankan koleksinya 
secara fulltext melalui internet. Sejumlah komponen yang telah dikembangkan pada perpustakaan perguruan tinggi di malang tersebut hampir secara keseluruhan telah membuktikan upaya yang keras dalam mengembangkan perpustakaan digital. Hal tersebut dibuktikan adanya komponen pengembangan koleksi baik pada aspek organisasional, mekanisasi, otomasi dan komunikasi informasi serta legalitas informasi sebagai implementasi pengembangan perpustakaan digital. Dalam mengembangkan perpustakaan digital menyangkut aspek manajemen, teknologi, kebijakan/hukum dan nilai budaya.

Perpustakaan Pusat Universitas Brawijaya (UB) menggunakan Sistem informasi Inlis-Lite v.3, dengan database perpustakaan digital Brawijaya Knowledge Garden (BKG) serta pengembangan akses layanan digital pada Gazebo dan Terraz Digital. Pengembangan perpustakaan digital pada Perpustakaan Universitas Malang (UM) dengan sistem informasi Sipadu berbasis metadata local serta memiliki koleksi digital dengan database Mulok serta pengembangan akses pada Café Pustaka. Profil pengembangan perpustakaan digital pada UIN Malang dengan mengimplementasikan sistem informasi Slims berbasis metadata doublin core dengan database E-These dan didukung Corner Pustaka.

Tabel 1 Ringkasan Perbandingan Perpustakaan Digital Pada Perpustakaan Perguruan Tinggi

Negeri di Malang Jawa Timur

\begin{tabular}{|c|l|l|l|l|}
\hline No. & $\begin{array}{c}\text { Aspek } \\
\text { Implementasi }\end{array}$ & $\begin{array}{c}\text { Universitas } \\
\text { Brawijaya } \\
\text { (UB) }\end{array}$ & $\begin{array}{c}\text { Universitas } \\
\text { Negeri } \\
\text { Malang (UM) }\end{array}$ & $\begin{array}{c}\text { Universitas } \\
\text { Islam Negeri } \\
\text { (UIN) } \\
\text { Malang }\end{array}$ \\
\hline 1. & Database & $\begin{array}{l}\text { Gazebo, } \\
\text { BKG Corner, } \\
\text { Sampurna } \\
\text { Corner }\end{array}$ & $\begin{array}{l}\text { Café Pustaka } \\
\text { disertai Wif/ } \\
\text { hotspot }\end{array}$ & $\begin{array}{l}\text { E-Thesis dan } \\
\text { Arabic Corner } \\
\text { dan Sudan } \\
\text { Corner, BI } \\
\text { Corner. }\end{array}$ \\
\hline
\end{tabular}

\begin{tabular}{|c|c|c|c|c|}
\hline 2. & Hardware & $\begin{array}{l}\text { Mengadakan } \\
\text { perangkat } \\
\text { keras untuk } \\
\text { komputer, } \\
\text { server, } \\
\text { jaringan dan } \\
\text { komputer } \\
\text { client baik } \\
\text { didalam } \\
\text { perpustakaan } \\
\text { maupun di } \\
\text { Terraz dan } \\
\text { Gazebo. }\end{array}$ & $\begin{array}{l}\text { Mengadakan } \\
\text { perangkat } \\
\text { keras untuk } \\
\text { komputer, } \\
\text { server, } \\
\text { jaringan dan } \\
\text { komputer } \\
\text { client di } \\
\text { Perpustakaan } \\
\text { maupun } \\
\text { di Terraz }\end{array}$ & $\begin{array}{l}\text { Mengadakan } \\
\text { perangkat } \\
\text { keras untuk } \\
\text { komputer, } \\
\text { server, jaringan } \\
\text { dan Komputer } \\
\text { client di } \\
\text { Perpustakaan. }\end{array}$ \\
\hline 3 & Software & $\begin{array}{l}\text { Inlis Lite } \\
\text { Versi } 3 \\
\text { Berbasis } \\
\text { Indomarc }\end{array}$ & $\begin{array}{l}\text { Sipadu } \\
\text { Berbasis } \\
\text { Lokal }\end{array}$ & $\begin{array}{l}\text { E-Print dan } \\
\text { Slims Berbasis } \\
\text { doubling core }\end{array}$ \\
\hline 4 & Fasiltas & $\begin{array}{l}\text { Brawijaya } \\
\text { Knowledge } \\
\text { Gerden dan } \\
\text { Instituational } \\
\text { Repository (IR) } \\
\text { Mobile library }\end{array}$ & $\begin{array}{l}\text { Muatan Lokal } \\
\text { (MULOC), } \\
\text { Café Pustaka } \\
\text { disertai Wifi/ } \\
\text { hotspot }\end{array}$ & $\begin{array}{l}\text { E-Thesis, Arabic } \\
\text { Corner, Sudan } \\
\text { Corner dan } \\
\text { Instituational } \\
\text { Repository (IR), } \\
\text { bookdrop }\end{array}$ \\
\hline
\end{tabular}

Sumber : Sintesa Peneliti

\section{Implementasi Perpustakaan Digital dalam Era Informasi}

Transformasi perpustakaan pada abad 21 telah diramalkan oleh para pakar, yaitu terkait perubahan konsep kepustakaan mulai dari tugastugas perpustakaan hingga sumber daya koleksi dan jasa layanan perpustakaan yang diberikan oleh perpustakaan digital. Prinsip dan konsep dalam perpustakaan digital lingkungan global sebagaimana dijelaskan oleh Teed bahwa adanya peran teknologi, manajemen keterampilan, organisasi akses, users dan services, interfaces design dan searching,dan browsing dan isu kekayaan intelektual (intellectual proverty) dalam sikap pengetahuan (knowledge attitudes) (Teed \& Large, 2005).

Dalam pengembangan perpustakaan digital baik secara teknis maupun non teknis sebagaimana disampaikan dalam Pendit dalam pengembangan perpustakaan digital terdapat 3 (tiga) aspek penting yang perlu diperhatikan (Pendit, 2009). Pertama, aspek organisasional. Dalam pengembangan perpustakaan digital, aspek organisasi merupakan infrastruktur penting dan 
strategis untuk mendapatkan perhatian. Selain itu, dalam aspek ini juga disinggung tentang organisasi informasi itu sendiri, yang mengalami perubahan mendasar sejak digunakannya komputer sebagai alat bantu penyimpanan dan penemuan kembali informasi. Kedua, aspek mekanisasi, otomatisasi, dan komunikasi informasi. Dalam pengembangan perpustakaan berbasis teknologi informasi, pengelolaan perpustakaan digital pada aspek mekanisasi, otomatisasi dan komunikasi informasi merupakan komponen kunci dan sangat menentukan sukses atau tidaknya dalam tahap implementasi atau pelaksanaan perpustakaan digital. Aspek ini meliputi infrastruktur teknologi informasi, metadata, sistem temu kembali informasi, jaringan telekomunikasi, internet dan web, dan teknik digitalisasi. Ketiga, aspek legalitas. Dalam pengembangan perpustakaan digital, aspek hukum dan etika dalam informasi menjadi sangat penting pada era informasi. Aspek legalitas menyangkut etika dalam digitalisasi, transaksi elektronik, hak cipta (intellectual property) dan plagiarisme. Sampai saat ini masih banyak perdebatan yang terjadi di berbagai kalangan masyarakat tentang bagaimana sebaiknya mengatur penggunaan teknologi digital agar tidak menimbulkan kebingungan dan kerancuan tentang hak serta kewajiban orang.

Pembangunan perpustakaan digital bagi masyarakat tidak akan lepas dari keinginan untuk saling berbagi. Dalam hal ini, perpustakaan berusaha untuk berbagi informasi kepada para pemustaka yang membutuhkan. Oleh karena itu, pembangunan perpustakaan digital perlu disesuaikan dengan kondisi pemustaka yang dilayani. Idealnya, sebelum mendesain dan mengaplikasikan sesuatu yang baru, termasuk perpustakaan digital, terlebih dahulu dilakukan analisa terhadap kebutuhan pemustakan (Teed \& Large, 2005). Hal ini dilakukan terutama untuk mengetahui informasi apa yang mereka butuhkan ketika berkunjung ke perpustakaan digital. Selain itu, hasil analisis nantinya akan memengaruhi desain model perpustakaan digital yang akan diimplementasikan. Oleh karena itu, dalam implementasinya, sebaiknya perpustakaan digital menyediakan ruang yang akan memberikan kesempatan bagi pemustaka untuk saling berbagi informasi, termasuk bagaimana pengembangan perpustakaan digital ke depan.

Dari uraian di atas dapat dijelaskan bahwa implementasi perpustakaan digital diperlukan strategi pengembangan perpustakaan digital berbasis nilai nilai-nilai Islam multicultural, yakni dalam rangka atau tujuan sebagai berikut: (a) memahami keanekaragaman budaya dalam merancang dan mendesain perpustakaan digital; (b) menghargai koleksi perpustakaan digital untuk memenuhi kebutuhan informasi pemustaka yang beraneka ragam; (c) mengembangkan sumber daya manusia secara professional; (d) berinteraksi dengan teknologi informasi dengan lancar; dan (e) membangun kesadaran kritis terhadap regulasi kebijakan akses perpustakaan digital.

\section{Urgensi Nilai Islam Multikultural dalam Pengembangan Perpustakaan Digital}

Kehadiran perpustakaan digital tersebut diharapkan mengatasi kesenjangan dalam akses informasi masyarakat. Kendala utama dalam pengembangan perpustakaan digital pada perguruan tinggi pada umumnya adalah belum optimalnya aksesibilitas informasi. Permasalahan aksesibilitas informasi tersebut disebabkan oleh beberapa faktor, antara lain masalah manajemen, teknologi, kebijakan dan regulasi akses hingga dengan masalah sosial budaya. Dalam pengelolaan perpustakaan digital, di samping masalah teknis dan manajerial, nilai-nilai keberagaman masyarakat merupakan pilar penting dalam pengembangan demokrasi informasi, inovasi teknologi, dan keadilan dalam legalitas informasi yang dapat melayani aksesibilitas masyarakat secara demokratis dan berkeadilan. 
Integrasi Nilai Islam Multikultural dalam Pengembangan Perpustakaan Digital: Studi Kasus pada Perpustakaan Perguruan Tinggi Negeri di Malang Jawa Timur Hartono

Bila diperhatikan, dalam pengembangan perpustakaan digital perguruan tinggi dapat dilihat dari tiga hal berikut pertama, dilihat dari aspek strategi. Ini ditunjukkan pada masing-masing perpustakaan perguruan tinggi negeri di Malang di mana perpustakaan digital memiliki strategi yang berbeda-beda baik dalam strategi membangun konsep dan desain, strategi dalam pengembangan koleksi digital, strategi manajemen sumber daya manusia (SDM), maupun strategi dalam menetapkan kebijakan akses informasi. Kedua, pengembangan perpustakaan digital dapat dilihat pada sistem dan teknologi informasi dalam upaya membangun aksesibilitas informasi. Dalam membangun aksesibilitas informasi sangat bervariasi. Hal ini dapat dilihat dari penyediaan infrastruktur teknologi informasi, sistem temu balik informasi, mengorganisasi dan metadata, jaringan internet dan kerjasama perpustakaan (resource sharing). Ketiga, pengembangan perpustakaan dapat dilihat dari pada nilai-nilai Islam multikultural. Hal ini dapat dilihat dari pengembangan perpustakaan digital yang bersumber pada nilai-nilai keragaman budaya seperti sikap, norma, nilai, dan perilaku.

Gambaran integrasi nilai multikultural dalam pengembangan perpustakaan digital dapat dilihat dalam tabel berikut ini :

\section{Tabel 1.4}

Ringkasan Integrasi Nilai Multikultural dalam Pengembangan Perpustakaan Digital pada Perpustakaan Perguruan Tinggi Negeri di Malang

\begin{tabular}{|c|c|c|c|}
\hline \multirow{2}{*}{$\begin{array}{l}\text { Aspek/ } \\
\text { Subjek }\end{array}$} & \multicolumn{3}{|c|}{ Perguruan Tinggi } \\
\hline & UB & UM & UIN \\
\hline Demokrasi & $\begin{array}{l}\text { Demokrasi } \\
\text { dengan } \\
\text { membangun } \\
\text { Brawijaya } \\
\text { Knowledge } \\
\text { Garden } \\
\text { (BKG) yang } \\
\text { dapatdiakses } \\
\text { terbuka (open } \\
\text { access) melalui } \\
\text { Aplikasi Inlis } \\
\text { Lite v.3, }\end{array}$ & $\begin{array}{l}\text { Demokrasi dalam } \\
\text { mengembangkan } \\
\text { koleksi muatan } \\
\text { local (MULOK) yang } \\
\text { bisa diakses secara } \\
\text { terbuka melalui } \\
\text { aplikasi Sipadu. }\end{array}$ & $\begin{array}{l}\text { Demokrasi dalam } \\
\text { melestarikan local } \\
\text { conten (LOCO) yang } \\
\text { dapat diakses terbuka } \\
\text { pada aplikasi E-Print }\end{array}$ \\
\hline
\end{tabular}

\begin{tabular}{|c|c|c|c|}
\hline Humanisme & $\begin{array}{l}\text { Humanisme } \\
\text { membangun } \\
\text { fasilitas gazebo } \\
\text { digital }\end{array}$ & $\begin{array}{l}\text { Humanisme } \\
\text { mengembangkan } \\
\text { café pustaka }\end{array}$ & $\begin{array}{l}\text { Humanisme } \\
\text { mendayagunakan } \\
\text { Corner Pustaka }\end{array}$ \\
\hline Keadilan & $\begin{array}{l}\text { Keadilan } \\
\text { memportalisasi } \\
\text { dalam sebuah } \\
\text { navigasi } \\
\text { kejahatan } \\
\text { informasi } \\
\text { (cybercrime) }\end{array}$ & $\begin{array}{l}\text { Keadilan melalui } \\
\text { mensosialisasi } \\
\text { undang-undang hak } \\
\text { cipta }\end{array}$ & $\begin{array}{l}\text { Keadilan } \\
\text { mengimplemantasikan } \\
\text { aplikasi plagiarisasi } \\
\text { (plagiarism Chexcher) }\end{array}$ \\
\hline Kebersamaan & $\begin{array}{l}\text { Kebersamaan } \\
\text { membangun } \\
\text { jaringan } \\
\text { informasi digital } \\
\text { (networks) }\end{array}$ & $\begin{array}{l}\text { Kebersamaan } \\
\text { mengembangkan } \\
\text { kerjasama } \\
\text { perpustakaan } \\
\text { digital (library } \\
\text { cooperations) }\end{array}$ & $\begin{array}{l}\text { Kebersamaan } \\
\text { mendayagunakan upaya } \\
\text { dalam berbagi sumber } \\
\text { daya koleksi digital } \\
\text { (resource sharing) }\end{array}$ \\
\hline Toleransi & $\begin{array}{l}\text { Toleransi dalam } \\
\text { mengembangkan } \\
\text { layanan berbasis } \\
\text { teknologi } \\
\text { informasi }\end{array}$ & $\begin{array}{l}\text { Toleransi dengan } \\
\text { menghargai } \\
\text { pengguna } \\
\text { kebutuhan informasi }\end{array}$ & $\begin{array}{l}\text { Toleransi dengan } \\
\text { membangun kesadaran } \\
\text { melalui regulasi akses } \\
\text { terbuka secara tertulis }\end{array}$ \\
\hline
\end{tabular}

Sumber: Sintesa Peneliti

Dalam upaya memperjelas "Pola integrasi Pengembangan Perpustakaan Digital dalam Membangun Aksesibilitas Informasi Berbasis Nilai Islam Multikultural" dapat dijelaskan sebagai berikut :

\section{Demokrasi Informasi Layanan Berbasis "Open Access"}

Demokrasi informasi merupakan kegiatan dalam upaya mengembangkan layanan jasa perpustakaan yang memungkinkan keterbukaan informasi (open access) yang dikembangkan oleh manajemen perpustakaan modern. Konsep open access merujuk kepada aneka jasa informasi digital yang tersedia secara terpasang (online), gratis (free of charge), dan terbebas dari semua ikatan atau hambatan hak cipta atau lisensi. Artinya, ada sebuah penyedia yang meletakkan berbagai berkas, dan setiap berkas itu disediakan untuk siapa saja yang dapat mengakses. Kebijakan keterbukaan informasi tersebut dirancang untuk membangun aksesibilitas informasi.

Dalam upaya membangun demokrasi informasi tersebut perpustakaan perguruan tinggi diperlukan upaya dalam perancangan, tata kelola, manajemen dan kebijakan dalam pengaturan akses perpustakaan digital. Strategi 
Implementasi manajemen perpustakaan digital pada Perpustakaan Perguruan Tinggi yang telah dilakukan pada perpustakaan perguruan tinggi di Malang dalam bentuk "Pola Implementasi Manajemen" adalah sebagai berikut: (a) melakukan rancang bangun perpustakaan digital dalam pembangunan perpustakaan digital melalui desain dan perancangan yang matang; (b) mengembangkan manajemen sumberdaya manusia (SDM) secara professional baik melalui pendidikan, pelatihan maupun bimtek yang dibutuhkan; (c) melaksanakan pengembangan koleksi digital yang beragam berasarkan azas pendirian perpustakaan; (d) mengembangkan layanan perpustakaan yang bervariasi dan inovatif dan (e) Menyusun kebijakan akses secara tertulis yang mengatur dalam etika informasi, hak cipta, plagiarism dan masalah kejahatan informasi (cybercrime).

\section{Humanisme dalam Modernitas Teknologi Digital}

Dalam konteks pengembangan perpustakaan digital bahwa humanisme merupakan nilai multikultural dalam Islam yang sangat mempengaruhi keberhasilan tugas, fungsi, dan tujuan perpustakaan digital. Dalam memahami keanekaragaman budaya terhadap pengembangan perpustakaan digital tersebut ada peran interaksi manusia melalui penyediaan infrastruktur baik gedung, fasilitas teknologi informasi perpustakaan digital, memahami sistem temu balik informasi untuk memenuhi kebutuhan informasi pemustaka yang beraneka ragam, komitmen dalam mengembangkan sistem metadata yang tepat bagi masyarakat yang beragam, mengembangkan sistem informasi dan teknologi informasi dengan lancar guna membangun interoperabilitas antara perpustakaan; dan menyediakan sistem internet yang memadai dalam berbagi sumber daya perpustakaan digital.

Implementasi nilai humanisme dalam modernitas teknologi informasi pada pengembangan perpustakaan digital sangatlah bervariasi pada Universitas Brawijaya Malang misalnya integrasi humanisme perpustakaan digital dapat kita lihat dari beberapa aspek antara lain pertama, bagaimana mengembangkan fasilitas yang lengkap dan mudah untuk mengakses dengan dilengkapi gazebo, komputer, jaringan dan colokan listrik yang sangat memadai, kedua,membangun jaringan internet melalui suplay bandwidth dan sistem informasi yang lancar dan ketiga, mengembangkan desain teknologi perpustakaan digital untuk mengatasi masalah bahasa antara lain dengan aplikasi Aplikasi Voice Announcement multibahasa.

Kemudian implementasi nilai humanisme terhadap modernitas teknologi informasi perpustakaan digital pada Universitas Negeri Malang (UM) nilai humanisme dapat diimplementasikan sebagai berikut: pertama,pengembangan fasilitas gedung dan ruangan kedua, sistem penelusuran yang cepat dan nyaman dan ketiga, mengembangkan layanan terraz digital dan café pustaka yang modern untuk mendukung aksesibilitas informasi. Pengembangan humanisme dalam modernitas teknologi informasi juga terjadi pada Universitas Islam Negeri Malang antara lain dilakukan aktivitas sebagai berikut: pertama, mengembangkan corner perpustakaan digitalyang dilengkapi meja baca dan komputer dan jaringan yang memadai, kedua, memberikan fasilitas desain teknologi perpustakaan digital untuk mengatasi masalah bahasa melalui program literasi informasi dan ketiga memberikan fasilitas dan pelayanan perpustakaan digital bagi pemustaka berkebutuhan khusus (diffabel).

\section{Keadilan Akses dalam Legalitas Informasi}

Dalam konsep perpustakaan digital bahwa hak kekayaan intelektual (intellectual property) merupakan bagian integral dalam pengembangan 
layanan perpustakaan digital. Dalam perspektif sosial bahwa dalam dunia digital mengenal suatu kaidah etis yang disebut sebagai kaidah penggandaan (copynorms). Istilah tersebut diartikan sebagai suatu standar sosial yang terkait dengan etika pangadaan materi-materi yang dilindungi hak cipta. Dalam hal ini pengadaan materi yang dilindungi hak cipta tanpa izin dari pemegang hak yang sah dipandang sebagai suatu perbuatan yang tidak etis, isu ini mulai muncul setelah maraknya aktifitas sistem pertukaran data.

Berkaitan legalitas informasi dapat dijelaskan bahwa dalam masalah hukum sangat berhubungan erat dengan legalitas informasi yang akan berbanding lurus dengan akesibilitas informasi. Aspek hukum dalam informasi berkaitan dengan etika mencari informasi, masalah hak kekayaan intelektual atau Haki, masalah plagiarism dan masalah undang-undang transaksi elektronik. Dengan adanya kebijakan dan regulasi akses informasi akan memberikan kepastian masyarakat kepada masyarakat dalam mencari informasi sekaligus membangun kemudahan dalam mendapatkan informasi. Dengan terbangunnya aksesibilitas informasi maka akan terpenuhinya kebutuhan masyarakat dalam upaya untuk membangun segala aspek kehidupannya bagi masyarakat informasi.

Dalam perspektif hukum bahwa perpustakaan perlu memperhatikan pengaturan tentang hak dan kewajiban dalam cara menyajikan, menyimpan, menyebarkan dan menggunakan informasi dalam kegiatan pendidikan tinggi. Perpustakaan juga masih bekerja dengan prinsip-prinsip legal dan etika yang didasarkan pada tradisi cetak. Manakala teknologi digital membawa ciri-ciri baru ke dunia kepustakawanan, maka adalah tugas pustakawan untuk memahami aturan-aturan baru yang diperlukan agar kegiatan perpustakaan tetap pada koridor hukum yang berlaku di sebuah masyarakat. Aspek etis dan yuridis yang harus menjadi perhatian pihak yang terkait dengan digitalisasi, baik pengguna sistem (user), pengembang sistem (developer), maupun penyelenggara sistem (operator). Digitalisasi menimbulkan tata cara baru dalam emanfaatkan data, informasi dan pengetahuan, sehingga ketiga pihak perlu menyepakati aturan baru pula (Pendit, 2009).

\section{Kebersamaan dalam Jaringan Informasi Resource Sharring}

Dalam konteks pengembangan perpustakaan digital, nilai kebersamaan yang merupakan nilai Islam multikultural yang memiliki potensi yang dapat dikembangkan. Dalam pengembangan perpustakaan digital dalam rangka membangun aksesibilitas informasi, implementasi nilai kebersamaan atau kerjasama diarahkan pada berbagai maksud dan tujuan, antara lain kebersamaan dalam memahami keanekaragaman budaya melalui kerjasama jaringan informasi pada perpustakaan digital, kebersamaan dalam menghargai kerjasama perpustakaan digital untuk memenuhi kebutuhan informasi pemustaka yang beraneka ragam dan kebersamaan dalam mengembangkan kerjasama antar perpustakaan.

Implementasi nilai kebersamaan dalam mengembangkan jaringan kerjasama perpustakaan pada Universitas Brawijaya, antara lain sebagai berikut: pertama, mengembangkan jaringan perpustakaan digital berbasis pada rumusan kesepakatan memorium of understanding (MoU), kedua pengembangan kerjasama jaringan perpustakaan digital pada bidang subjek multidisiplin dan ketiga kerjasama dan jaringan informasi digital memiliki ruang lingkup pada pengembangan akses koleksi perpustakaan dengan penguatan teknologi informasi, keempat mengedepankan jaringan informasi pada jangkauan nasional dan internasional. 


\section{Toleransi Jasa Kemitraan Layanan Perpustakaan Digital}

Dalam konteks pengembangan perpustakaan digital, toleransi berupa sikap mengakui, menerima, dan menghargai merupakan nilai Islam multikultural dan dapat diarahkan untuk mempengaruhi keberhasilan tugas, fungsi, dan tujuan perpustakaan digital, antara lain: pertama, membangun toleransi dalam menghargai keanekaragaman dalam masyarakat yang dilayani; kedua, toleransi mengakui dalam mengembangkan koleksi; ketiga, saling menghargai dalam memenuhi kebutuhan informasi pemustaka yang beraneka ragam melalui kerjasama; keempat, saling memahami dalam mengembangkan akses informasi kepada masyarakat, kelima saling berbagi dalam berinteraksi berbagi sumber informasi menggunakan teknologi informasi dengan lancar dan keenam, toleransi dalam bersikap membangun kesadaran kritis terhadap regulasi kebijakan akses perpustakaan digital.

Strategi integrasi nilai multikultural dalam pengembangan perpustakaan digital" dapat digambarkan sebagai berikut :

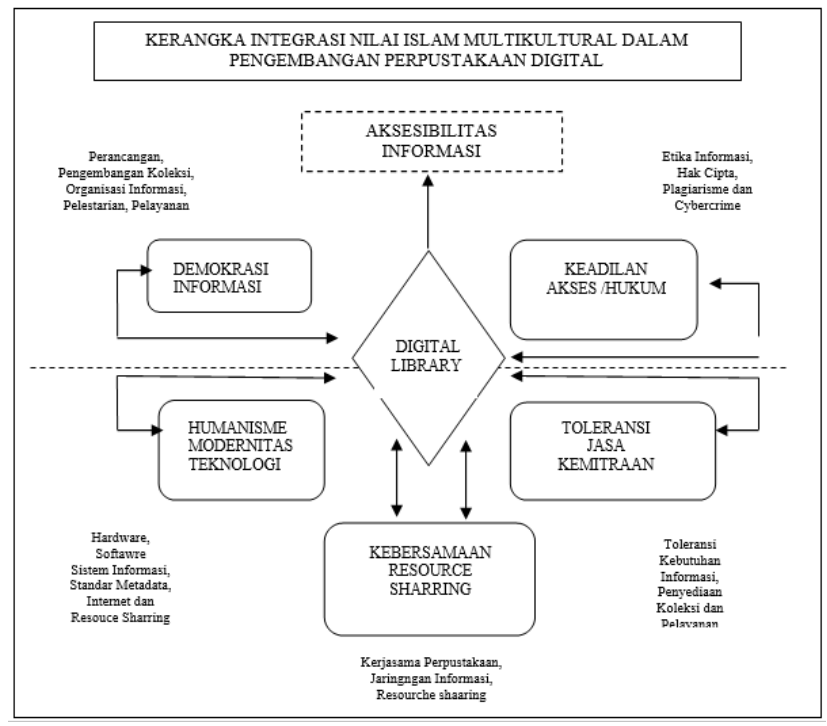

Gambar 3 Kerangka Integrasi Nilai Multikultural dalam Pengembangan Perpustakaan Digital

\section{E. PENUTUP}

Simpulan

Berdasarkan penjelasan yang telah dipaparkan, dapat ditarik kesimpulan yaitu:

1. Implementasi perpustakaan digital pada Perpustakaan Perguruan Tinggi Negeri di Malang (UB, UM dan UIN) telah berjalan sebagaimana adanya namun terdapat 4 (empat) permasalahan utama yang harus diatasi antara lain masalah perencanaan perpustakaan digital, aspek manajemen sumber daya manusia belum memadai, belum adanya kebijakan pengembangan koleksi digital yang beragam dan layanan yang bervariasi, keempat, belum memiliki kebijakan tertulis yang mengatur terhadap regulasiakses, penerapan hak cipta, plagiarisme dan masalah kejahatan dalam informasi (cybercrime).

2. Terdapat 3 (tiga) kendala dalam pengembangan teknologi informasi digital pada Perpustakaan Perguruan Tinggi Negeri di Malang (UB, UM dan UIN) yaitu belum optimalnya pengembangan infrastruktur teknologi perpustakaan digital baik, serta sistem temu balik informasi (information retrieval) belum memadai.

3. Integrasi Nilai Islam Multikultural dalam Pengembangan Perpustakaan Digital pada Perpustakaan Perguruan Tinggi di Malang didasarkan pada 5 (lima) aspek nilai Islam multikultural antara lain demokrasi, humanisme, keadilan, kebersamaan dan nilai toleransi.

\section{Saran}

Pertama, bagi Kementerian Riset Teknologi dan Pendidikan Tinggi dan Kementerian Agama dari pusat sampai tingkat kabupaten/kota, agar benar-benar serius dalam mengimplementasikan pengembangan perpustakaan digital dalam membangun aksesibilitas informasi berbasis nilai 
Islam multikultural.

Kedua, kepala perpustakaan perguruan tinggi dalam penyelenggaraan perpustakaan digital berbasis nilai multikultural, supaya terus menerus meningkatkan kualitas implementasi program perpustakaan digital. Antara lain dengan mengimpelentasi "pola implementasi manajemen" perpustakaan digital dengan penguatan pada konsep dan perancangan, pengembangan akses koleksi secara terbuka, manajemen sumber daya manusia profesional, dan penyusunan akses dan regulasi akses informasi.

Ketiga, bagi para pemerhati dan ahli di bidang pendidikan dan studi budaya (cultural studies) di Indonesia, hasil penelitian ini agar dijadikan salah satu pijakan asumsi, betapa masih rapuhnya pengembangan perpustakaan yang berorientasi pana aspek praktis dan mekanis yang selama ini diselenggarakan di Indonesia

\section{DAFTAR PUSTAKA}

Aly, A. (2011). Pendidikan Islam Multikultural: Pelaah terhadap Kurikulum Pesantren Modern Islam Assalam. Surakarta: Pustaka Pelajar.

Baidhawy, Z. (2005). Pendidikan Agama Berwawasan Multikultural. Jakarta: Erlangga.

Bounfour, A. (2016). Digital Futures, Digital Transformation: From Lean Production to Acceluction. London: Springer.

Calhoun, K. (2014). Exploring Digital Libraries: Foundations, Practice, Prospects. London: Facet Publishing.

Gollnick, D. M., \& Chin, P. C. (1998). Multicultural Education in Pluralistic Society. Ney Jersey: Prentice Hall.

Laksmi. (2006). Tinjauan Kultural terhadap Kepustakawanan: Inspirasi dari Sebuah Karya Umberto Eco. Depok: Departemen IImu Perpustakaan dan Informasi Fakultas IImu Pengetahuan Budaya Universitas Indonesia.
Ostrov, R. (1998). Library Culture in Electronic Age: A Case Study of Organizational Change. Proquest Disertations \& Thesis.

Pendit, P. L. (2009). Perpustakaan Digital: Perspektif Perpustakaan Perguruan Tinggi Indonesia. Jakarta: Sagung Seto.

Rifai, A. (2013). Perpustakaan Islam. Konsep dan Kontribusinya dalam Membangun Peradaban Islam dan Masa Klasik. Jakarta: Raja Grafindo Persada.

Sadri, M., \& Sadri, A. (2000). Reason, Freedom, and Democracy in Islam: Essensial writings of Abdorkarim Soroush. New York: Oxford University.

Supriyanto, W., \& Muhsin, A. (2008). Teknologi Informasi Perpustakaan: Strategi Perancangan Perpustakaan Digital. Yogyakarta: Kanisius.

Teed, L. A., \& Large, A. (2005). Digital Libraries: Priciples and Preactice in a Global Environment. Munchen: K.G Saur.

Zulaikha, S. R. (2010). Kontribusi Teori Ranganathan dalam Perkembangan Perpustakaan di Indonesia. Kuliah Program Pascasarjana, UIN Sunan Kalijaga, 3-4. Yogyakarta. 